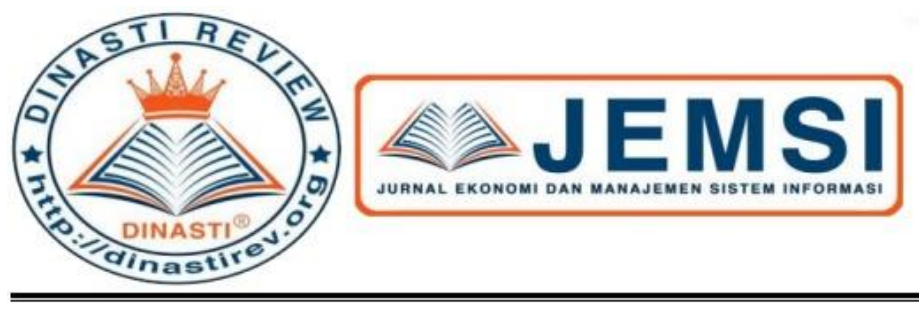

+62 878-9658-6407

087896586407 ()

https://dinastirev.org/JEMSI (-)

editor@dinastirev.org (.)

\title{
PENERAPAN ETIKA BISNIS PADA PT INDAH JAYA LONDRINDO
}

\section{Yessy Arsita}

Universitas Mercubuana, Jakarta, Indonesia.

ARTICLE INFORMATION

Received: 2 Mei 2020

Revised: 14 Juni 2020

Issued: 19 Juli 2020

Corresponding author: first author

E-mail: yessyarsita@ymail.com

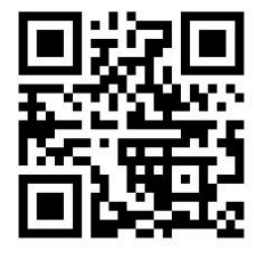

DOI:10.31933/JEMSI
Abstrak: Penelitian ini bertujuan untuk menganalisis penerapan bisnis yang diterapkan pada PT Indah Jaya Londrindo. Sehingga peneliti akan melakukan penelitian yang berjudul " Penerapan Etika Bisnis pada PT Indah Jaya Londrindo". Jenis penelitian ini adalah penelitian kualitatif deskriptif demi mendapatkan informasi dengan cermat untuk megetahui penerapan etika bisnis pada PT Indah Jaya Londrindo dimana penerapan konsep dilakukan menggunakan tehnik wawancara terhadap 3 informan yaitu, general PT Indah Jaya Londrindo, HRD PT Indah Jaya Londrindo dan masyarakat lingkungan sekitar PT Indah Jaya Londrindo. Temuan penelitian ini menunjukkan bahwa penerapan etka bisnis di PT Indah Jaya Londrindo belum baik. Etika bisnis yang diterapkan oleh PT Indah Jaya Londrindo lebih dominan dengan menetapkan etika relativisme. Sehingga dapat dikatakan implementasi etika bisnis dalam perusahaan ini belum sempurna.

Kata Kunci: Etika bisnis, etika deskriptif, etika normatif.

\section{PENDAHULUAN}

Etika merupakan kepercayaan tentang tindakan yang benar dan yang salah yang akan mempengaruhi hal lainnya. Moral dan nilai pribadi seseorang dalam konteks sosial menentukan etis atau tidak nya suatu perilaku. Dengan kata lain, perilaku etis merupakan keyakinan yang seseorang dan norma-norma sosial yang diterima oleh masyarakat umum yang dianggap baik dan benar. Perilaku tidak etis adalah perilaku yang tidak dapat diterima oleh masyarakat umum karena dianggap buruk. Disadari ataupun tidak nilai etika yang diyakini tersebut ,baik secara langsung ataupun tidak langsung, akan ikut serta menciptakan terjalinnya macam-macam pola dan proses interaksi antar individu maupun kelompok. Muncul nya etika itu sendiri terbentuk dan bersumber dari budaya, agama, pendidikan keluarga, pergaulan, pendidikan ataupun hasil renungan dari berbagai bacaan.

Bisnis adalah kegiatan organisasi yang didalam nya terdapat kegiatan pertukaran barang dan jasa ataupun keduanya dengan customer. Dalam ilmu perekonomian bisnis merupakan suatu organisasi yg menjual jasa atau barang demi mendapatkan laba. Menurut sejarah kata bisnis merupaka kata yang berasal dari bahasa inggris "Business", dari kata busy yang berarti "sibuk" dalam konteks individu, komunitas ataupun masyarakat. Dalam artian, sibuk mengajarkan aktivitas dan pekerjaan yang mendatangkan keuntungan. 
Banyak akademisi mempresepsikan etika sebagai tuntutan budaya atau penilaian tertentu yang dijadikan dasar dalam membangun suatu peradaban dan pengkondisian tahap kedewasaan suatu masyarakat. Ini berarti, jika perilaku bisnis dikaitkan secara konteks dengan etika, maka hal ini memaksa aktivitas bisnis sebagai pengejewantahan perilaku sosial semua orang, menuju cita-cita terciptanya kesejahteraan bersama, dimana semua pemikiran ini secara tidak langsung terarah pada terbentuk nya rasa akan tanggung jawab sosial bersama.

Etika bisnis merupakan istilah yang biasanya berkaitan dengan perilaku etis atau tidak etis yang dilakukan oleh manajer atau pemilik suatu organisasi (Ricky W. Griffin dan Ronald J. Ebert, 2007). Etika bisnis adalah cara-cara berprilaku yang dilakukan untuk menjalankan kegiatan bisnis secara adil dan sesuai hukum yang berlaku yang mencakup seluruh individu, perusahaan, industri dan juga masyarkat. Etika bisnis dalam suatu perusahaan dapat membentuk perilaku pimpinan serta karyawan dalam menciptakan hubungan yang adil dan sehat.

Setiap perusahaan meyakini bisnis yang beretika adalah prinsip bisnis yang baik, yaitu kinerja bisnis yang unggul dan berkesinambungan dengan mentaati pedoman-pedoman etika dibarengi dengan hukum yang berlaku.

Oleh karena itu, didalam setiap hal yang berhubungan dengan etika bisnis pasti akan terkandung bobot etika sosialnya. Jika dilihat lebih jauh lagi, etika bisnis akhirnya merupakan bagian sosial dari peradaban masyarakat. Sudah menjadi keharusan, bahwa di setiap jenis bisnis apapun tidak lagi semata-mata hanya mencari keuntungan maksimal bagi perusahaan, tetapi harus juga memikirkan tujuan personal dari pada para karyawan yang telah mendedikasikan dirinya.

Dalam menjalani kehidupan di zaman sekarang ini keberadaan etika bisnis sangatlah penting dikarenakan beberapa hal:

1. Bagi perekenomian masyarkat global yang sudah maju, akan senantiasa berharap dan butuh kehadiran kinerja etika bisnis yang tinggi. Saat ini terlihat nyata bahwa organisasi bisnis yang memiliki kinerja etika yang tinggi akan sangat cepat memperoleh dukungan dan pembenaran seluruh nya kiprah bisnis nya dari masyarakat luas. Kondisi seperti ini mampu menumbuhkan suasana saling menguntungkan antara dunia bisnis dan masyarakat, sehingga memungkinkan terciptanya kerjasama, kemitraan sejati yang egaliter, demi meraih manfaat ekonomis sekaligus sosial dari setiap aktivitas bisnis. Tetapi sangat disayangkan sekali, jika dilihat dari kasus di Indonesia, dikarenakan etika bisnis belum menjadi acuan moral kolektif anak bangsa, justru kinerja etika bisnis yang tinggi adakalanya malah tereliminasi karena praktik persaingan yang tidak sehat. Masyarakat pun seringkali tidak ambil pusing dengan etika bisnis, misalnya saja dengan membeli barang-barang bajakan dan selundupan apalagi hukumpu belum berdiri kokoh untuk memberikan perindungan.

2. Kepatutan bertindak etika yang dilakukan organisasi ataupun pekerjanya, agar menghindari dari berbagai kemungkinan terjadinya kerugian sosial ataupun material terhadap kelompok pemangku kepentingan dalam masyarakat.

3. Usaha untuk melindungi atmosfir bisnis dan hadirnya kemungkinan buruk akan perilaku-perilaku nonetikal, yang bersumber dari internal perusahaan maupun eksternal perusahaan. 
4. Tingginya kinerja etikal secara otomatis akan melindungi karyawan yang bekerja dilingkungan bisnis dari situasi kerja yang melanggar moralitas .

5. Pada dasarnya setiap individu ingin bertindak konsisten dengan norma etikal yang diyakini nya. Bilamana terdapat pertentangan antara individu dengan organisasi tempat bekerja dalam waktu yang kurun lama akan berdampak pada penurunan kreatvitas dan produktivitas seseorang dalam bekerja. Maka dari itu iklim etikal yang kondusif dan konsisten akan memberikan ketenangan batin dan kenyamanan psikologis bagi pekerja.

Bisa dikatakan probolematika etika bisnis, dari skala kecil hingga skala besar, tidak saja terjadi disekitaran bumi nusantara, tetapi kenyataannya terjadi belahan dunia manapun dan masih sering dijumpai praktik bisnis yang mengabaikan tanggung jawab sosial. Seiring berjalannya waktu, fenomena atau isu mengenai etika bisnis pun berubah-ubah tematiknya. Jika biasanya peroblematika etika bisnis berkutat pada fenomena dan isu seputar deskriminasi gender dan ras, kesenjangan upah dan gaji, pemutusan hubungan kerja, objektivitas penilaian prestasi kinerja, maka dimasa mendatang isu-isu tersebut akan berpindah tekanannya ke tema yang menyangkut kelestarian lingkungan hidup kesehatan dan keselamatan pekerja, kemanan produk, kerahasiaan informasi, kemiskinan global, pelanggaran hak cipta, dan besaran penguasaan kepemilikan yang diperbolehkan.

Di indonesia sendiri, saat ini penerapan etika bisnis cenderung terasa menyedihkan, karena masih lemahnya moralitas para pengusaha dibarengi pula oleh marut nya perundangundangan dan hilangnya wibawa penegak hukum karena citranya kerap tercoreng perilaku koruptif. Jika kondisi demikian terus-menerus berlarut-larut tanpa adanya upaya serius, konsepsional dan konsisten untuk memperbaikinya, kemungkinan buntunya kehidupan perekonomian seklaigus terbuka kemungkinan menjadi amat terkucilkan kiprah pelaku bisnis dari ajang pergaulan kaum investor.

Berdasarkan asumsi diatas, maka penulis ingin mengetahui bagaimana penerapan etika bisnis yang dilakukan perusahaan dengan judul "PENERAPAN ETIKA BISNIS

\section{PADA PT INDAH JAYA LONDRINDO".}

\section{KAJIAN PUSTAKA}

Etika berasal dari bahasa Yunani ethos (kata tunggal) yang berarti: tempat tinggal, padang rumput, kandang, kebiasaan, adat, watak, sikap, cara berpikir. Bentuk jamaknya ialah ta, etha, yang berarti adat istiadat. Dalam hal ini, kata etika sama pengertianya dengan moral. Moral berasal dari kata latin: Mos (bentuk tunggal), atau mores (bentuk jamak) yang artinya kebiasaan, adat istiadat, kelakuan, watak, cara hidup ,tabiat, akhlak(Nata, 2012).

Etika didalam bahasa arab disebut sebagai akhlak, merupakan jamak dari kata khuluq yang berarti perangai, adat kebiasaan, watak, tabiat, adab, dan agama (Alfan, 2011). Berkembangnya pemahaman mengenai pengertian etika tidak lepas dari beberapa substansinya bahwa etika merupaka ilmu yang membicarakan suatu masalah perbuatan atau tingkah laku manusia, dimana yang dinilai baik dan mana dinilai yang jahat.

Pengertian secara umum, etika merupakan suatu norma atau aturan yang digunakan untuk pedoman dalam berperilaku dalam masyarakat bagi seseorang terkait dengan sifat baik ataupun buruk.

Etika dapat digolongkan ke dalam 2 macam menurut Keraf (1991:23), yaitu: 
a. Etika Deskriptif

Etika deskriptif adalah usaha menilai tindakan atau prilaku berdasarkan pada ketentuan atau norma baik buruk yang tumbuh dalam kehidupan bersama di dalam masyarakat. Kerangka etika ini pada dasarnya menempatkan kebiasaan yang sudah ada di dalam masyarakat sebagai acuan etis. Suatu tindakan seseorang disebut etis atau tidak. Tergantung pada kesesuaiannya dengan yang dilakukan kebanyakan orang.

b. Etika Normatif

Pada etika ini , masyarakat cenderung lebih mendasar pada sifat dasar kesusilaan didalam berperilaku, manusia menjadikan norma kesusilaan sebagai panutannya. Etika menetapkan bahwa setiap individu memakai norma-norma sebagai panutannya dalam berpiralku dalam lingkungannya, tetapi tidak memberikan tanggapan mengenai kelayakan suatu ukuran-ukuran kesusilaan. Sah atau tidaknya norma- norma tetap tidak dipersoalkan yang di perhatikan hanya berlakunya saja.

Menurut Bukhori Alma (1993:2), bisnis merupakan sejumlah total usaha yang meliputi produksi, distribusi, pertanian, konstruksi, transportasi, komunikasi, usaha jasa dan pemerintah, yang bergerak di bidang membuat dan memasarkan barang dan jasa pada konsumen.

Menurut Louis E. Boone (2007:5), bisnis (bussines) terdiri dari semua aktivitas dan usaha untuk mencari keuntungan dengan menyediakan barang dan jasa yang dibutuhkan bagi sistem perekonomian, beberapa bisnis memproduksi barang berwujud sedangkan yang lain memberikan jasa.

Ada beberapa macam jenis bisnis menurut Indriyo Gito Sudarmo (1993: 3), yaitu :

1) Ekstraktif, merupakan jenis kegiatan bisnis di bidang pertambangan seperti menggali bahan tambang yang ada didalam perut bumi.

2) Agraria, merupakan bisnis yang bergerak bidang sector pertanian.

3) Industri, yaitu bisnis yang bergerak dalam bidang industri.

4) Jasa, merupakan kegiatan bisnis yang bergerak dibidang pelayanan yang menghasilkan produk yang tidak berwujud dan disajikan dalam bentuk pelayanan baik secara individu atau kelompok.

Menurut Velasquez (2005), Etika bisnis merupakan pembelajaran yang dikhususkan mengenai ilmu moral yang mengajarkan sesuatu yg benar dan salah. Studi ini difokuskan pada standar moral yang diterapkan dalam kebijakan, institusi, dan perilaku bisnis.

Hapzi Ali (2020), mendefinisikan etika bisnis sebagai suatu cabang dari filosofi yang berkaitan dengan kebaikan atau moralitas dari perilaku manusia.

Etika bisnis memiliki tujuan memberikan dorongan kepada kesadaran moral dan untuk memberikan batasan bagi para pengusaha ataupun pebisnis agar dapat mengelola bisnis secara adil dan jujur serta menghindari diri dari kegiatan bisnis curang yang dapat merugikan banyak orang atau pihak yang memiliki keterikatan satu sama lain.

Selain itu, etika bisnis juga memiliki tujuan supaya bisnis dapat dijalankan dan tercipta seadil mungkin serta sesuai dengan hukum yang telah disetujui . Etika 
bisnis dapat memberikan motivasi kepada para pelaku bisnis agar terus meningkatkan kemampuan mereka dalam mengolah bisnis.

Serta etika bisnis ditujukan untuk menjauhkan suatu bisnis atau pelaku bisnis dari citra yang tidak baik karena biasanya perusahaan atau pembisnis yang tidak memiliki etika bisnis yang baik dapat merugikan orang lain dan akhirnya merusak bisnis nya sendiri.

\section{METODE PENELITIAN}

Dalam penyusunan makalah ini, penulis melakukan penelitian pada PT Indah Jaya Londrindo yang terletak di Jl. Padjajaran 14 no 62 Gandasari, Jatiuwung, Tangerang dengan mengambil objek penelitian dengan judul "PENERAPAN ETIKA BISNIS PADA PT. INDAH JAYA LONDRINDO“.

Secara umum penelitian dapat diartikan sebagai suatu proses analisis dan pengumpulan data yang dilakukan secara logis dan sistematis untuk memperoleh tujuantujuan tertentu. Menurut Sugiyono (2012 : 2) dalam bukunya yang berjudul Metode Penelitian Kuantitatif, Kualitatif dan R\&D menyatakan bahwa : "Metode penelitian merupakan cara ilmiah untuk mendapatkan data dengan tujuan dan kegunaan tertentu".

Dalam penelitian ini, peneliti menggunakan jenis penelitian kualitatif deskriptif. Penelitian kualitatif adalah penelitian yang bertujuan untuk mengerti fenomena tentang sesuatu yang dialami oleh subjek penelitian, secara holistik, dengan cara deskripsi dalam bentuk bahasa dan kata-kata, pada suatu konteks khusus yang alamiah dengan memanfaatkan berbagai metode alamiah (Moleong,2013). Ada 11 karakteristik dalam penelitian kualitatif , salah satunya adalah deskriptif . Ciri dari penelitian deskriptif adalah data yang dikumpulkan berupa gambar dan kata-kata bukan angka-angka. Data tersebut bisa didapatkan dari hasil wawancara, foto, catatan lapangan, dokumen pribadi dan dokumen resmi lainnya (Moleong 2013).

Sumber data yang digunakan dalam penelitian ini ada dua macam, yaitu : sumber data primer pada penelitian ini berasal dari hasil wawancara dan observasi yang dilakukan PT Indah Jaya Londrindo, dan sumber data sekunder dari penelitian ini bersumber dari dokumendokumen perusahaan.

\section{HASIL DAN PEMBAHASAN}

PT Indah Jaya Londrindo yang beralamat di Jl. Padjajaran 14 no 62 Gandasari, Jatiuwung Tangerang, merupakan perusahaan yang bergerak dalam bidang jasa laundry dan telah berdiri sejak tahun 2012. Perusahaan ini dimiliki oleh Bpk. Ivan Pesik selaku Direktur Utama yang mempunyai kuasa penuh dalam memimpin seluruh bagian di dalam perusahaan. PT Indah Jaya Londrindo merupakan perusahaan penyedia jasa pencucian laundry. PT. PT Indah Jaya Londrindo telah melayani berbagai perhotelan di daerah Jakarta dan Tangerang. Selain penyedia jasa Laundry PT Indah Jaya Londrindo juga menyewakan handuk kepada hotel untuk memenuhi kebutuhan pelanggan. PT Indah Jaya Londrindo juga memiliki visi dan misi yakni menjadi pemimpin pasar dalam industri jasa binatu terpadu yang akan datang serta memberikan layanan dan solusi binatu yg berkualitas dan efisien. PT Indah Jaya Londrindo memiliki visi menjadi penyedia jasa laundry kelas dunia, yang menjadi tolak ukur kualitas bagi perusahaan jasa laundry lainnya. Selain itu misi PT Indah Jaya Londrindo adalah untuk menghasilkan jasa berkualitas tinggi dengan tetap mempertahankan harga yang kompetitif. Untuk memberikan dan mempertahankan layanan terbaik pada customer kami. 
Untuk terus meningkatkan karyawan, teknologi, dan proses kami. Untuk menjaga akuntabilitas sosial terhadap karyawan kami dengan menyediakan lingkungan kerja yang ramah lingkungan dan sadar kesehatan lingkungan.

Setiap perusahaan pasti mempunyai tujuan yang akan dicapai sebelumnya, dimana untuk mencapai tujuan tersebut, setiap perusahaan memerlukan struktur organisasi yang berbentuk suatu bagan organisasi sebagai alat untuk pencapaian tujuan. Struktur organisasi perusahaan merupakan suatu proses pencapaian dan perkembangan pekerjaan yang dilakukan atas dasar pengelompokkan tugas dan wewenang dalam organisasi sehingga dapat saling bekerjasama dengan baik.

Dengan adanya struktur organisasi yang dimiliki oleh perusahaan memiliki peranan yang sangat penting bagi perusahaan itu sendiri, karena dengan struktur organisasi yang telah tersusun dengan baik dapat menciptakan sistem kerja yang teratur serta menciptakan suatu hubungan kerjasama yang baik di dalam lingkungan organisasi tersebut.

\section{Struktur Organisasi}

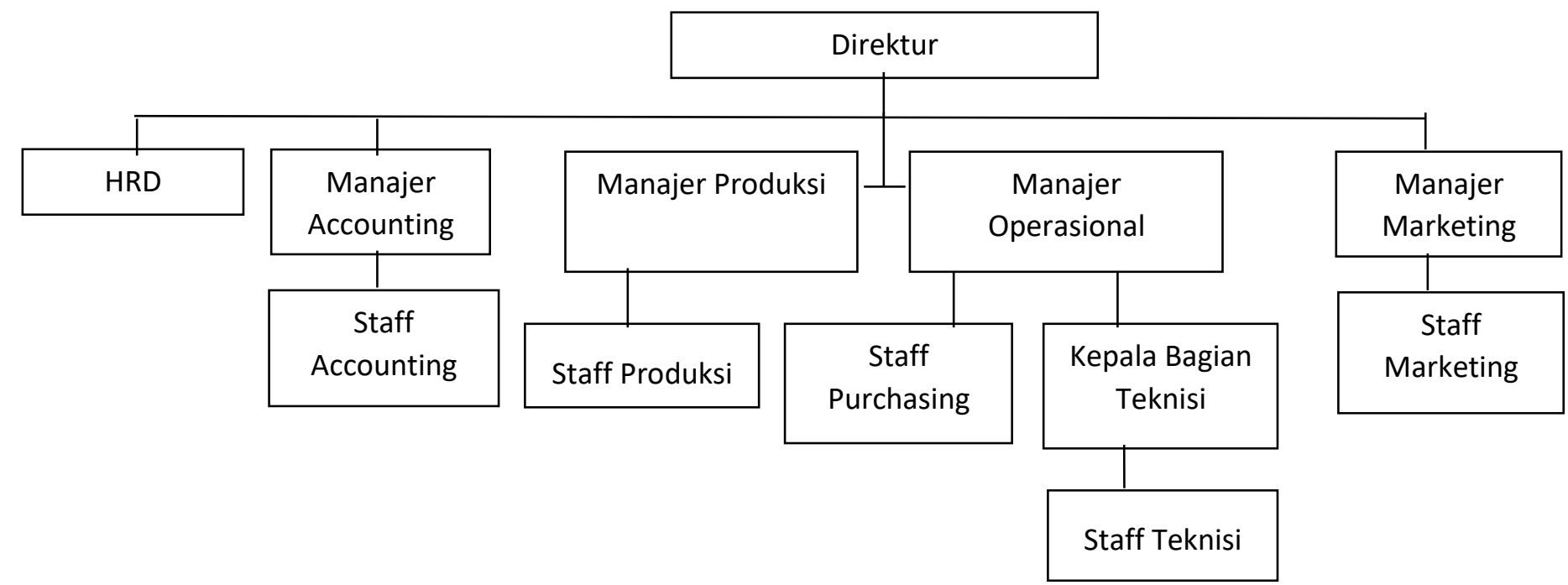

\section{Sumber : PT. INDAH JAYA LONDRINDO}

Pedoman perilaku bagi suatu perusahaan merupakan suatu hal yang penting. Pedoman perilaku dapat memberikan panduan serta arahan bagaimana suatu perusahaan berperilaku sesuai harapan perusahaan sehingga akan menjadi suatu prilaku khas yang membedakan PT Indah Jaya Londrindo dengan perusahaan lainnya. Dari hasil wawancara dan observasi PT Indah Jaya Londrindo menerapkan perturan didasarkan pada hukum yang berlaku sesuai kaidah dan norma dalam masyarakat serta bekesinambungan dengan tujuan perusaahaan yaitu menciptakan suasana kerja yang nyaman bagi karyawan. Hal tersebut terbukti dengan hasil wawancara general manager PT Indah Jaya Londrindo yang menyatakan bahwa ada nya sanksi tegas baik bagi karyawan ataupun atasan yang melanggar. Hal ini sejalan dengan pernyataan divisi HRD PT Indah Jaya Londrindo. Namun dari hasil wawancara dengan karyawan PT Indah Jaya Londrindo, penetapan peraturan didasarkan pada kewenangan atasan, dimana apabila karyawan melanggar kode etik yang ditetapkan perusahaan makan 
atasan berhak langsung memberikan sanksi berupa sanksi ringan atau sanksi berat (PHK) tanpa mengkaji ulang kode etik yang telah di buat di perusahaan.

Dari hal tersebut peneliti menyadari bahwa mengapa karyawan bisa melakukan pelanggaran kode etik tersebut?. Dari hasil wawancara dengan divisi HRD ditemukan tidak ada nya pelatihan keterampilan kerja secara khusus dan menyeluruh. Namun perusahaan menyadari bahwa keterampilan khusus sangat penting untuk dilakukan . Pelatihan yang dilakukan biasanya hanya untuk meningkatkan skill dan attitude dalam perusahaan. PT Indah Jaya Londrindo menerima calon karyawan yang berpengalaman dengan memberikan masa percobaan 3 bulan lamanya untuk menyeleksi calon karyawan. Didalam masa percobaan tersebut, calon karyawan memperoleh peningkatan skill dan attitude. Pernyataan general manager dan divisi HRD PT Indah Jaya Londrindo mensyatakan bahwan penempatan karyawan berdasarkan skill yang dimiliki oleh karyawan dan standar kerja perusahaan dan bukan berdasarkan aspek penghasilan.

Etika terhadap lingkungan dan sosial pada PT Indah Jaya Londrindo, menerapkan etika deontologi. Dengan tegas PT Indah Jaya Londrindo mengatakan melakukan pengolahan limbah dan bersosialisasi kepada masyarakat sekitar perusahaan dan memberikan upah sesuai ketetapan pemerintah. Hal ini diperkuat dengan pernyataan masyarakat lingkungan sekitar yang membenarkan hal tersebut dengan pernyataan bahwa memang benar adanya perusahaan melakukan pengolahan limbah dan bersosialisasi dengan masyarakat dan memberikan kesempatan kerja yang sama kepada masyarakat sekitar perusahaan.

PT Indah Jaya Londrindo menjalin hubungan dengan relasi bisnis, berusaha berbisnis secara jujur, tanpa kedok dan terbuka kepada pelanggan. PT Indah Jaya Londrindo juga adil dalam pelayanan kepada pelanggan tanpa melihat dari status sosial nya, karena perusahaan menyadari semua pelanggan harus mendapatkan hak pelayanan yang sama. Dalam hal tanggung jawab PT Indah Jaya Londrindo sudah cukup membuktikannya dari pemberian informasi kepada pelanggan tanpa menyesatkan, dan memberikan garansi sehingga pelanggan merasa aman.

Muatan kode etik internal PT Indah Jaya Londrindo dijelaskan sebagai berikut :

\section{Kewajiban karyawan}

1. Sikap Karyawan di dalam Perseroan:

- Menjadi setiap bagian dari Perseroan yang baik dengan mentaati kebijakan internal perseroan /ketentuan Perseroan, peraturan perusahaan serta peraturan perundangan yang berlaku didalam Perseroan.

- Mengembangkan dan menggunakan potensinya secara optimal untuk kepentingan Perseroan.

- Ikut serta dalam menciptakan budaya kerja yang baik dan bersama-sama membangun lingkungan kerja yang kondusif.

2. Sikap Karyawan dalam menggunakan jabatan dan wewenangnya di Perseroan:

- Menggunakan jabatan dan wewenang yang diberikan dengan penuh tanggung jawab, digunakan untuk kepentingan Perseroan dan bukan untuk kepentingan pribadi atau pihak-pihak tertentu 
- Menggunakan dan menjaga seluruh informasi, data, harta dan fasilitas perusahaan untuk kepentingan Perseroan, bukan untuk kepentingan pribadi atau pihak-pihak tertentu

- Menjaga nama baik Perseroan dalam sikap dan perilakunya, baik di luar lingkungan maupun di dalam lingkungan Perseroan

3. Sikap Karyawan terkait dengan Informasi bersifat Rahasia milik Perseroan Informasi bersifat Rahasia milik Perseroan adalah sekumpulan dokumen dan/atau sekumpulan informasi strategis yang dibuat dan/atau diperoleh Perseroan yang tidak boleh dibeberkan dan diinfokan kepada pihak luar. Semua Karyawan ikut serta bertanggung jawab untuk menjaga kerahasiaan dan dilarang menyalahgunakan Informasi bersifat Rahasia Perseroan. Informasi bersifat Rahasia Perseroan yang didapatkan karyawan Perseroan selama beekrja di Perseroan harus tetap dirahasiakan setelah masa kerjanya di Perseroan berakhir.

4. Hubungan sesama Karyawan:

- Saling mendorong semangat, menghargai, dan membina kerjasama dalam menjalankan tanggung jawab dan tugas nya masing-masing.

- Membangun keterbukaan dan meningkatkan integritas serta mentalitas kelimpahruahan (abundance mentality) dengan hubungan yang harmonis sebagai warga Perseroan.

\section{Kewajiban management}

\section{Pengelolaan Kepegawaian}

Pegawai adalah setiap orang, baik yang berstatus kontrak atau tetap, langsung dan tidak langsung, yang bekerja untuk Perusahaan. Pengelolaan kepegawaian harus mampu mendorong tingkat produktivitas untuk mencapai kinerja terbaiknya serta menjadi seorang insan yang beretika.

2. Keselamatan, Kesehatan serta Lingkungan Kerja Implementasi standar Keselamatan dan Kesehatan serta Lingkungan Kerja yang tinggi, merupakan tanggung jawab bersama dari pimpinan dan seluruh Insan Perusahaan.

3. Kesempatan yang Sama, Pelecehan, Ancaman dan Kekerasan Setiap pegawai berhak atas lingkungan kerja yang bebas dari diskriminasi, pelecehan, dan ancaman.

Muatan kode etik eksternal PT Indah Jaya Londrindo dijelaskan sebagai berikut :

\section{Hubungan dengan Pemegang Saham}

Setiap individu yang menjadi bagian dari perusahaan berkomitmen untuk senantiasa berusaha keras agar Perusahaan mampu bertumbuh secara berkesinambungan berdasarkan prinsip bisnis yang saling menguntungkan satu sama lain hingga dapat memberikan kontribusi yang optimal bagi Pemegang Saham.

\section{Hubungan dengan Pemegang Pelanggan}

Perusahaan berkomitmen memenuhi seluruh kontrak penjualan yang telah disepakati dalam upaya meningkatkan kepuasan pelanggan dan memenuhi pasokan energi bagi pelanggan. 


\section{Hubungan dengan Kreditor/Investor}

Perusahaan melakukan kerjasama dengan kreditur/investor dalam mengajukan bantuan pendanaan untuk kepentingan perluasan usaha dan peningkatan kinerja Perusahaan.

\section{Hubungan dengan Pemasok}

Perusahaan melakukan kerjasama dengan pemasok dalam rangka memenuhi segala kebutuhan perusahaan untuk mendapatkan barang dan jasa yang berkualitas dengan harga kompetitif sehingga terjaminnya rantai pasokan Perusahaan.

\section{KESIMPULAN DAN SARAN}

Etika merupakan suatu norma atau aturan yang digunakan untuk pedoman dalam berperilaku dalam masyarakat bagi seseorang terkait dengan sifat baik ataupun buruk.

Penerapan etika bisnis di PT Indah Jaya Londrindo secara singkat dapat disimpulkan :

1. Perusahaan menciptakan pedoman perilaku sebagai panduan bagaimana suatu perusahaan berperilaku sesuai dengan harapan perusahaan sehingga dapat menjadi perilaku khas yang membedakan dengan perusahaan lainnya

2. Perusahaan menjamin terlaksana nya kewajiban karyawan dan perusahaan dalam kode etik yang telah ditentukan.

3. Perusahaan menjamin penerapan etika terhadap mitra usaha (Eksternal).

Saran yang dapat diberikan oleh penulis adalah, sebagai berikut :

1. Perlunya dukungan dari semua divisi, terkat pelaksanaan pedoman perilaku, terutama dari top management yang menjadi acuan para karyawan dalam berprilaku.

2. Perlunya pelatihan yang tepat dan mendalam sesuai dengan profesi masing-masing karyawan demi meminimalisir pelanggaran etika.

\section{DAFTAR RUJUKAN}

1. Griffin, Ricky W \& Ebert, Ronald J. 2007. Bisnis Edisi Kedelapan. Jakarta: Erlangga.

2. Abuddin, Nata. 2012. Akhlak Tasawuf dan Karakter Mulia. Jakarta: Raja Grafindo.

3. Alfan, Muhammad, 2011. Filsafat Etika Islam. Bandung: CV Pustaka Setia.

4. Keraf, A. Sonny.1991. Etika Bisnis : Membangun Citra Bisnis Sebagai Profesi Luhur (Pustaka Filsafat). Yogyakarta: Kanisius.

5. Buchari, Alma. 1993. Pengantar Bisnis. Bandung: Alfa Beta.

6. Boone, Louis E, David L Kurtz. 2007. Pengantar Bisnis Kontemporer, Edisi ke Sebelas.Jakarta: Salemba Empat

7. Reksohadiprodjo, Sukanto dan Gitosudarmo, Indriyo. 1993. Manajemen Produksi Edisi Keempat. Yogyakarta: BPFE.

8. Velasquez, Manuel G. 2005. Etika Bisnis,Konsep dan Kasus, Edisi 5. Yogyakarta: Penerbit Andi.

9. Sugiyono. 2012. Metode Penelitian Kuantitatif Kualitatif dan R\&D. Bandung: Alfabeta.

10. Ali, Hapzi. 2020. Modul Business Ethics \& Good Governance. Universitas Mercu Buana.Jakarta.

11. Moleong, Lexy J. 2013. Metode Penelitian Kualitatif. Edisi Revisi. Bandung PT.Remaja Rosdakarya. 